Local Knowledge and Agricultural Decision

Making in the Philippines 
Food Systems and Agrarian Change

Edited by Frederick H. Buttel, Billie R. DeWalt, and Per Pinstrup-Andersen

A complete list of titles in the series appears at the end of this book. 


\section{LOCAL KNOWLEDGE}

AND AGRICULTURAL

DECISION MAKING

\section{IN THE PHILIPPINES}

Class, Gender, and Resistance

Virginia D. Nazarea-Sandoval

Cornell University Press 
Copyright $@ 1995$ by Cornell University

All rights reserved. Except for brief quotations in a review, this book, or parts thereof, must not be reproduced in any form without permission in writing from the publisher. For information, address Cornell University Press, Sage House, 5 I 2 East State Street, Ithaca, New York 14850.

First published 1995 by Cornell University Press.

Printed in the United States of America

(2) The paper in this book meets the minimum requirements of the American National Standard for Information Sciences Permanence of Paper for Printed Library Materials, ANSI Z39.48-I984.

Library of Congress Cataloging-in-Publication Data

Nazarea-Sandoval, Virginia D.

Local knowledge and agricultural decision making in the Philippines : class, gender, and resistance / Virginia D. Nazarea Sandoval.

p. cm. - (Food systems and agrarian change)

"Based on one year of ethnographic fieldwork in Kabaritan from August 1986 to September I987"-Pref.

Includes bibliographical references (p. ) and index.

ISBN o-80I4-280I-7 (alk. paper)

I. Rural development - Philippines - Kabaritan. 2. Traditional farming Philippines - Kabaritan. 3. Agriculture - Philippines - Kabaritan-Decision making. 4. Food habits - Philippines - Kabaritan. 5. Kabaritan (Philippines)Social life and customs. I. Title. II. Series.

$\mathrm{HN}_{720 . Z}{ }_{9} \mathrm{C}_{664} \mathrm{I}_{7} \quad \mathrm{x} 995$

$338.9599^{\prime} \mathrm{I}-\mathrm{dc} 20$ 